\title{
THE EFFECT OF VOCABULARY MASTERY ON STUDENTS' WRITING SKILL (RESEARCH ON GRADE VIII STUDENTS AT SMP NEGERI 46 JAKARTA)
}

\author{
Resa Siti Maesaroh ${ }^{1}$, Reknosari $^{2}$ \\ 1,2 Universitas Indraprasta PGRI \\ Jalan Nangka No. 58C, Jagakarsa, Tanjung Barat, Jakarta Selatan 12530, Indonesia
}

Corresponding Author(S): sarirekno@gmail.com

\begin{abstract}
:
The aim of this study is to find out the Effect of Vocabulary Mastery on Students' Writing Skill. The approach of this study is quantitative. The research is conducted at SMP Negeri 46 Jakarta, the total sample of this research followed by 20 students of grade VIII at SMP Negeri 46 Jakarta. The sampling technique is probability random sampling. The techniques of collecting data used are test to get the vocabulary mastery score and writing skill to know of students' writing skill of description text. The techniques of analyzing data used simple linear regression and significant test. The result of analysis shows that there is positive effect students' vocabulary mastery on students' writing skill of grade VIII at SMP Negeri 46 Jakarta. This is obtained from the data, the value of $F_{\text {count }}$ $>F_{\text {table }}$ is a value of $F_{\text {count }} 5,67 \geq F_{\text {count }} 4.74$, which show $F_{\text {count }}>F_{\text {table. }}$
\end{abstract}

\section{Keywords:}

Vocabulary Mastery, Students' Writing

Skill

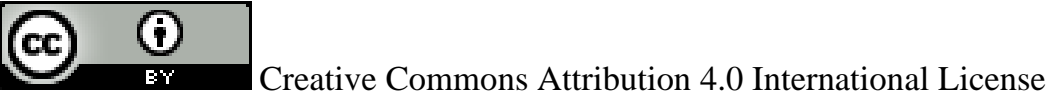

\section{INTRODUCTION}

In learning a language, vocabulary mastery is needed. By having a lot of vocabulary, it will make someone who learns a language becomes more fluently and confidence in expressing his ideas through spoken or written expression. Learning a language needs practice. In Indonesia, English is learnt by students from early stage of school level until higher level. Although English is not a second language, but it becomes a foreign language learnt in Indonesia. The role of English as a universal language has forced people to be fluently in English. Many media and articles are written in English. That is why English is so needed. Improving vocabulary mastery can be a door to make learning English more fun and easier.

According to Hatch and Brown (1995: 1), the term vocabulary refers to a list or set of words for particular language or a list of words that individual speakers of language use. It needs the process of learning in context to get the meaning of words as stated by Allen French (1983: 4). Hornby (1995: 985) states that vocabulary is the total number of the words (with their meaning and with rules for combining them) making up the language. Burns and Broman (1975: 295) define that vocabulary is the stock of words used by a person, class or professional, all having much in common, yet each distinctly 
different. The importance of mastering vocabulary in learning is also stated by Nunan. Nunan (1998: p. 118) says that, the development of a rich vocabulary is an important element in the acquisition of a second language.

According to Sullivan and Alba (2010) stated that without grammar very little can be conveyed, without vocabulary nothing can be conveyed.

Learning a language also needs to learn its grammar. Vocabulary is the basic unit in mastering grammar. In grammar words, sentences and rules are leant because in every language, they have different form and that makes learning a language more challenging.

According to Zuraina Ali (2012), learning vocabulary has few ways that student's need or enjoy they are student's attitudes in learning vocabulary using contextual clues, student's attitudes in learning vocabulary using dictionaries, student's attitudes in learning vocabulary using CALL.

Learning vocabulary in the classroom with interactive ways is a good solution. By choosing a good way in learning. It makes learning more fun and enjoyable for students. If a teacher can make the class environment becomes comfortable for students, then the knowledge can be transformed easily. The goal of learning also can be reached successfully.

According to Heinle (2011), says that vocabulary production is first analyzed, followed by an account of research examining learner's knowledge of dictionary words.

In learning vocabulary, using a dictionary can be useful. But we also have to know how to use a dictionary well. By knowing the root of words, it will help learners easily to find the meaning in a dictionary. By using a dictionary, we also can find the synonym, antonym and meaning of words based on context or the meaning based on our language used. By checking the meaning in a dictionary, then we can build sentences and paragraph as the next level of learning a language.

According to Naveen Kumar Mehta (2009), The following are the main methodologies for teaching vocabulary items in an English language classroom they are listening carefully, pronouncing the word, methods of grasping the meaning. More about vocabulary also stated by Saniago Dakhi and Tira Nur Fitria (2019), Types of vocabulary an account for the vocabulary types is important. It is in order to have a better understanding of how to teach students effectively according to context, learner's learning style and preferences, and needs. Two well-known categories are receptive and productive vocabulary, and active and passive vocabulary.

Students at junior high school in Indonesia learn English more in theory and very little in practice. There are at least four skills to be mastered in learning English. They are listening, speaking, reading and writing. They are related each other. By doing more listening practice, someone will be good in speaking. By doing more reading practice, someone will be good in writing. It is not easy for junior high school students to learn English well at school.

Learning English from text can be one of solutions in improving vocabulary mastery. In this research, writers choose descriptive text. This text fells suitable for junior high school learners who still need more practices with the limited vocabulary that they have. From a descriptive text, students can use their visualization to imagine and hope they can explore vocabulary mastery through text.

In writing descriptive text, students have to identify and describe person, animal, thing or place well. Descriptive text focuses on specific participant, uses of attributes, declarative sentence, simple present tense and make it in a short and simple. In an effort to master English requires continuous practice. But in reality this is not done by students. 
Many junior high school students are reluctant to use or practice English when teaching and learning takes place and their daily activities. This happens because English is a foreign language that is different from Indonesian in its language rules. People who are accustomed to using Indonesian certainly are not easy to use a foreign language. This difficulty has an impact on the lack of competency of students in learning English, especially in the aspect of writing.

Vocabulary mastery is closely related to writing skill. If in expressing ideas, both orally and in writing, students are not able to use the right words because the student does not know the meaning of certain words. This mistake or misunderstanding can cause students to have difficulty understanding what they are reading or what will be used when they speak or write.

\section{METHOD}

In this Research, the researcher used a quantitative method. The researcher used the survey method and effect analysis research design. The population of this study was all eighth-grade students of SMP Negeri 46 Jakarta. Because of the COVID 19 pandemic, the data collection use online media. Data obtained through interviews with other parties about the object and subject under study and study the documentation about the object and subject understudy". The researcher used the post-test. The test used is in the form of a multiple-choice test on vocabulary mastery and text writing tests on writing skills. The vocabulary mastery test consists of 20 multiple choice questions, and the text writing test consists of at least two paragraphs. Secondary data in this research are multiple-choice tests and writing tests submitted to students.

\section{RESULTS AND DISCUSSION}

This research started from March to June 2020. It was conducted at SMP Negeri 46 Jakarta, located at Jl. Rukun Pejaten Timur Pasar Minggu South Jakarta Indonesia. The respondents in this study are grade VIII students of SMP Negeri 46 Jakarta. Respondents in this study sample are 20 students. Respondents were given a test in the form of multiple choice and essay to find out how much mastery of their English vocabulary. Based on the descriptive of analysis obtained frequency distribution graph can be seen below.

\section{Data Analysis}

Figure 1 Histogram of Students' Vocabulary Mastery Test

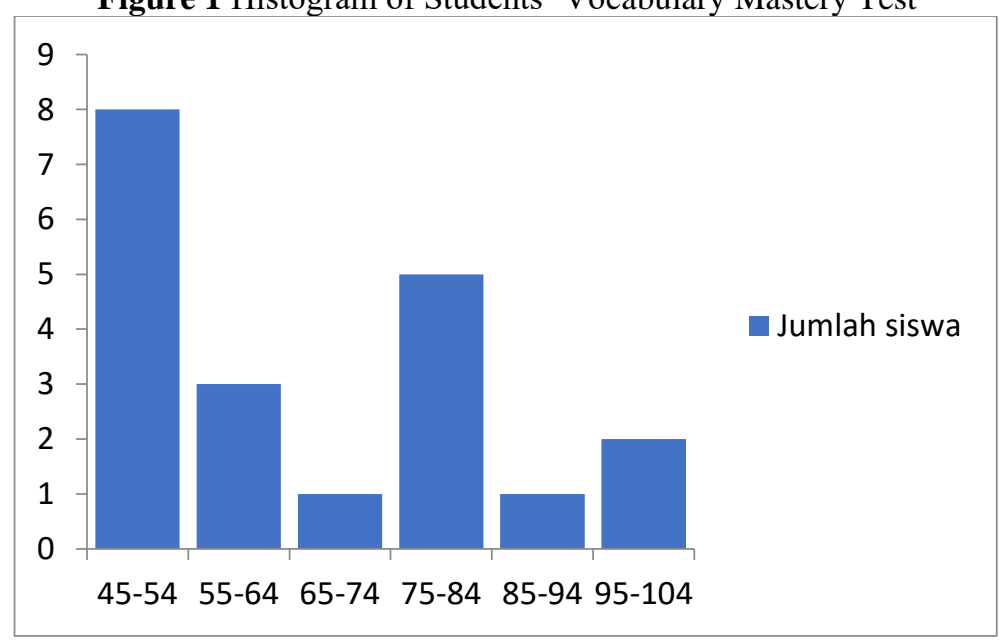


Figure 2 Grade VIII Students' Writing Skill Test Histogram

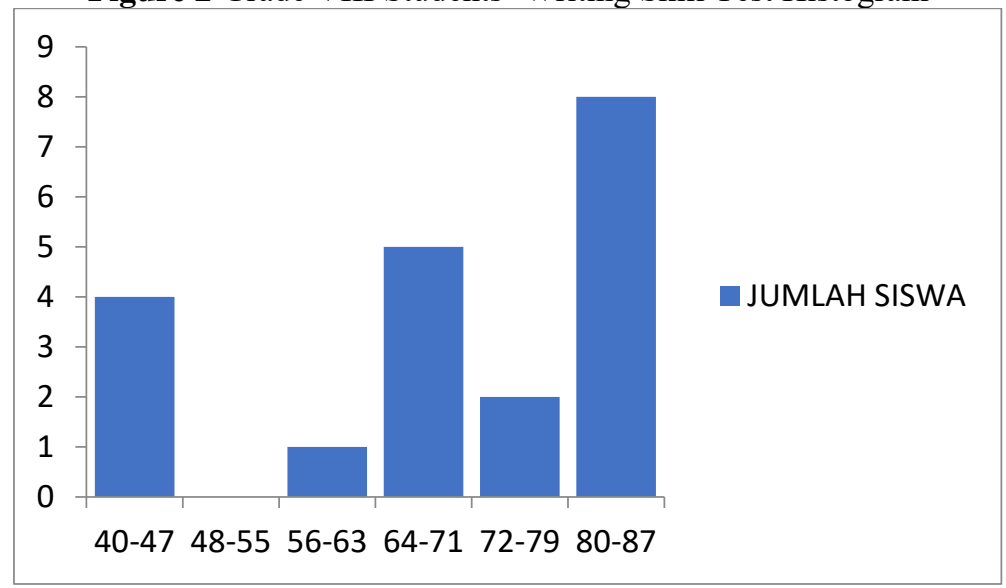

Table 1 Normality Test of Students' Vocabulary Mastery Test Score

\begin{tabular}{ccccccccc}
\hline $\mathbf{N o}$ & $\mathbf{Y i}$ & $\mathbf{F i}$ & $\mathbf{F k u m} \leq$ & $\mathbf{Z i}$ & $\mathbf{Z}$ table & $\mathbf{F}(\mathbf{Z i})$ & $\mathbf{S}(\mathbf{Z i})$ & $\begin{array}{c}\mathbf{F}(\mathbf{Z i})- \\
\mathbf{S}(\mathbf{Z i})\end{array}$ \\
\hline $\mathbf{1}$ & 45 & 5 & 5 & $-1,21$ & 0.1056 & 0,11 & 0,25 & $-0,14$ \\
$\mathbf{2}$ & 50 & 3 & 8 & $-0,93$ & 0,1711 & 0,18 & 0,4 & $-0,22$ \\
$\mathbf{3}$ & 55 & 1 & 9 & $-0,65$ & 0,2578 & 0,26 & 0,45 & $-0,19$ \\
$\mathbf{4}$ & 60 & 2 & 11 & $-0,37$ & 0,3632 & 0,36 & 0,55 & $-0,19$ \\
$\mathbf{5}$ & 65 & 1 & 12 & $-0,08$ & 0,4801 & 0,47 & 0,6 & $-0,13$ \\
$\mathbf{6}$ & 75 & 2 & 14 & 0,48 & 0,6736 & 0,68 & 0,7 & $-0,02$ \\
$\mathbf{7}$ & 80 & 3 & 17 & 0,76 & 0,7734 & 0,78 & 0,85 & $-0,07$ \\
$\mathbf{8}$ & 85 & 1 & 18 & 1,04 & 0,8531 & 0,85 & 0,9 & $-0,05$ \\
$\mathbf{9}$ & 100 & 2 & 20 & 1,88 & 0,9678 & 0,97 & 1 & $-0,03$ \\
\hline
\end{tabular}

Table 2 Normality Test of Students' Writing Skill Test Score

\begin{tabular}{ccccccccc}
\hline No & Yi & Fi & Fkum $\leq$ & $\mathbf{Z i}$ & $\mathbf{Z}$ table & $\mathbf{F}(\mathbf{Z i})$ & $\mathbf{S}(\mathbf{Z i})$ & $\begin{array}{c}\mathbf{F}(\mathbf{Z i})- \\
\mathbf{S}(\mathbf{Z i})\end{array}$ \\
\hline $\mathbf{1}$ & 40 & 4 & 4 & $-1,92$ & 0,0256 & 0,03 & 0,2 & $-0,17$ \\
$\mathbf{2}$ & 60 & 1 & 5 & $-0,62$ & 0,2578 & 0,27 & 0,25 & 0,02 \\
$\mathbf{3}$ & 65 & 1 & 6 & $-0,29$ & 0,4013 & 0,38 & 0,3 & 0,08 \\
$\mathbf{4}$ & 70 & 4 & 10 & 0,03 & 0,5199 & 0,51 & 0,5 & 0,01 \\
$\mathbf{5}$ & 75 & 2 & 12 & 0,36 & 0,6368 & 0,64 & 0,6 & 0,04 \\
$\mathbf{6}$ & 80 & 4 & 16 & 0,68 & 0,7422 & 0,75 & 0,8 & $-0,05$ \\
$\mathbf{7}$ & 85 & 4 & 20 & 1,01 & 0,8531 & 0,84 & 1 & $-0,16$ \\
\hline
\end{tabular}

The data of vocabulary test is normally distributed or not, based on table before obtained $\mathrm{L}$ count $=-0,02$ with the value based on the critical table $\mathrm{L}$ taken from the list of Lilifors test values. With a real level of $\alpha=0.05$ and $n=20$ obtained $L$ table $=0,19$. So that the value of $\mathrm{L}$ count $-0,02<0,19 \mathrm{~L}$ table, which means that the data is normally distributed. And to find out the data of writing skill is normally distributed or not, based on table before obtained L count $=0,08$ with the value based on the critical table $\mathrm{L}$ taken from the list of Lilifors test values.

Based on these calculations it turns out that the value of $F$ count $\geq F$ table is a value of $F$ count 5,67 $\geq F$ table 4.74, so that Ho is rejected which means significant. Based on these descriptions it can be concluded that there is an influence between the mastery of vocabulary on English writing skills. The data is linear patterned because with the 
value of $\mathrm{F}$ count $=1,02 \leq \mathrm{F}$ table 2,95 , then it is clear that there is an effect vocabulary mastery on students' writing skill.

\section{CONCLUSION}

Based on the research result, the writer concludes as follows:

1. There is an effect of vocabulary mastery on student's writing skill the value of F count $=1,02 \leq \mathrm{F}$ table 2,95 .

2. For the teachers, they can choose best methods to increase vocabulary mastery during the learning process and outside it. Vocabulary mastery can be very helpful for the students to increase the writing skill.

3. For the students, they can make their habit in vocabulary mastery by reading a book or anything that is in English, listen to the native speaker through videos on TV, YouTube or from English songs to increase their writing skill. While vocabulary be mastered, it will make easy to understand the English language.

4. For researchers, it is hoped that researchers can continue this research further, and able to find other factors that can affect students' vocabulary mastery to writing English text.

\section{REFERENCE}

Allen, V. F. (1983). Technique in Teaching Vocabulary. Oxford: Oxford University Press.

Ali, Z., Mukundan, J., Baki, R., \& Ayub, A. F. M. (2012). Second Language Learners' Attitudes towards the Methods of Learning Vocabulary. English Language Teaching, 5(4), 24-36.Burn, Paul C and Betty L. Broman. (1975). The language Arts in Childhood Education. A Rational for Pedagogy. Cambridge: Cambridge University Press.

Dakhi, S., \& Fitria, T. N. (2019). The Principles and the Teaching of English Vocabulary: A Review.

Hatch, E., \& Brown, C. (1995). Vocabulary, Semantics, and Language Education. Cambridge: Cambridge University Press.

Nation, I. S., \& Webb, S. A. (2011). Researching and analyzing vocabulary. Boston, MA: Heinle, Cengage Learning.Hornby, A.S. (1984). Oxford Advanced Learner's Dictionary of Current English.

Mehta, N. K. (2009). Vocabulary Teaching : Effective Methodologies. The Internet TESL Journal.

Sullivian, R. A., \& Alba, J. O. (2010). Criteria For EFL Course Books' Vocabulary Selection: Does It Have Any Practical Cosequences. 